\title{
Start-EU-up! Lessons from international incubation practices to address the challenges faced by Western European start-ups
}

\author{
Marijn van Weele ${ }^{1}$ (D) Frank J. van Rijnsoever ${ }^{1} \cdot$ \\ Chris P. Eveleens ${ }^{1} \cdot$ Henk Steinz ${ }^{1}$ Niels van Stijn ${ }^{1}$ • \\ Menno Groen ${ }^{1}$
}

Published online: 18 December 2016

(C) The Author(s) 2016. This article is published with open access at Springerlink.com

\begin{abstract}
Despite the continued efforts of policy makers, Western European start-ups are still struggling. Further, as questions are being raised about the effectiveness of incubators, there is a growing call for incubators around the world to learn from each other and improve themselves. Our paper enables Western European incubators to learn from their foreign peers by qualitatively exploring the challenges faced by Western European startups and the practices that incubators around the world use to address these challenges. Our study thereby takes a two-step approach. First, using the components of the entrepreneurial ecosystem to structure data coming from 90 qualitative interviews with Western European entrepreneurs and incubator managers, we explore five interrelated challenges that constrain the ability of Western European start-ups to grow into high-impact businesses. In the second part of our study, we conduct a total of 191 interviews in Silicon Valley, the greater Boston area, Israel and Australia to identify practices that incubators in these regions use to address the five challenges identified in the first study. Our findings suggest that, rather than addressing the underlying institutions that cause challenges in the entrepreneurial ecosystem, incubators provide symptomatic solutions by creating an environment that protects start-ups from unfavorable institutions. Accordingly, we conclude that existing incubators have only limited potential to strengthen entrepreneurial ecosystems, and we end our paper with a call for a new generation of 'systemic incubators' that aim to transform or create institutions to address the institutional challenges that constrain start-up activity.
\end{abstract}

Keywords Incubators - Start-ups · Regional development - Entrepreneurial ecosystem · Europe $\cdot$ Business support

JEL Classification M13 $\cdot \mathrm{O} 31 \cdot \mathrm{O} 38$

Marijn van Weele

m.a.vanweele@uu.nl

1 Innovation Studies, Copernicus Institute of Sustainable Development, Utrecht University, Utrecht, The Netherlands 


\section{Introduction}

Stimulating the emergence and growth of technology-based start-ups (hereafter: start-ups) has become a central part of Western European policies to achieve economic growth (Ahmad and Ingle 2013; Brown and Mason 2014). While these start-ups only constitute a small part of the total population of small businesses, policy makers see them as important drivers of employment and innovation (Brown and Mawson 2015; Michael and Pearce 2009). However, these start-ups suffer from high failure rates; about one-third of Western European start-ups do not survive their second year (Bartelsman 2005; Scarpetta et al. 2002). To offset the risks associated with start-ups, European governments increasingly support them through incubators: organizations that provide start-ups with a broad range of services and resources needed for survival and growth (Aerts et al. 2007; Bergek and Norrman 2008; Bruneel et al. 2012). It is estimated that there are currently over 1000 European incubators, $85 \%$ of which is located in Western European countries, and that their number has seen a fivefold increase between 2007 and 2013 (Aerts et al. 2007; Ahmad and Ingle 2013; Salido et al. 2013). Accordingly, incubators are considered to be 'the mainstays of high-technology industrial development in Europe' (Oakey 2012 p. 67), and 'an institutionalized component of the EU's and its member states' national innovation systems' (Ahmad and Ingle 2013 p. 123).

The efforts of Western European policy makers to support start-ups through incubators are in line with a global trend: the number of incubators increases rapidly around the world, which has led to a diverse global population of incubators and related start-up support initiatives (Aerts et al. 2007; Chandra et al. 2012). This provides an 'immense opportunity' for incubators all over the world to learn from each other and improve themselves (Ahmad and Ingle 2013 p. 131; see also Aernoudt 2004; Tavoletti 2013; Terjesen et al. 2013). Such learning is urgently needed, as questions are being raised about the effectiveness of incubators, in Western Europe (see e.g. Schwartz 2009, 2013; Tamásy 2007) and elsewhere (see e.g. Lewis 2001; Tavoletti 2013). Further, Western Europe still seems to be lagging behind other economies in terms of start-up activity (Startup Manifesto 2013; The Economist 2012; Tijssen and van Wijk 1999).

However, cross-national comparative studies on incubators are rare (Ahmad and Ingle 2013; Phan et al. 2005; Rothaermel et al. 2007). International studies that do exist (e.g. Aernoudt 2004; Lalkaka 2002; Lee and Osteryoung 2004; Lendner and Dowling 2007) have two limitations. First, they primarily provide comparisons of incubator attributes, such as configurations, objectives and historical underpinnings. Such analyses have been criticized for failing to explain how the incubation process unfolds. Accordingly, there is a growing call for scholars to move away from the incubator's attributes and towards the incubator's practices to explain in more detail how incubators provide their support (Ahmad and Ingle 2013; Hackett and Dilts 2004a, b; Phan et al. 2005). Second, existing studies pay little attention to the incubator's context. Doing so is important, as incubators enable start-ups to overcome constraints that may be specific to the local entrepreneurial ecosystem, such as a lack of venture capital or legitimacy for start-ups (Amezcua et al. 2013; Clarysse et al. 2005; Degroof and Roberts 2004). Identifying incubation practices therefore requires a thorough understanding of the challenges in the entrepreneurial ecosystem that incubators should address. However, although previous studies have looked at Europe's challenges for innovation and entrepreneurship (see e.g. Kelley et al. 2012; Tijssen and van Wijk 1999), none of these studies have looked at the specific challenges faced by the early-stage, technology based start-ups that are typically supported by 
incubators. It is important to do so, as these start-ups have unique characteristics that distinguish them from the greater small business population: they are young, technologydriven, and their founders often lack entrepreneurial experience (Bergek and Norrman 2008; Rice 2002). This may result in specific challenges faced by these start-ups compared to the more generic challenges identified by previous studies.

To address these limitations, our study answers two research questions. First, "what are the main challenges faced by start-ups in Western Europe?" Second, "which practices can incubators use to address these challenges in the Western European context?" We structure the identification of challenges around the concept of entrepreneurial ecosystems. To create a comparable group of countries, we study innovation driven economies (Kelley et al. 2012). These economies have a relatively high share of opportunity-driven entrepreneurship, which includes technology based start-ups, and are home to the majority of incubators and are therefore relevant for our study (Aerts et al. 2007). Empirically, we base our conclusions on two studies that use semi-structured interviews with entrepreneurs, incubator managers, and other key stakeholders in the entrepreneurial ecosystems of the Netherlands, Germany, Switzerland, France, the United States (Silicon Valley and the greater Boston area), Australia and Israel.

Our study contributes to the extant literature by exploring how incubators strengthen the entrepreneurial ecosystem. Our findings suggest that incubators provide symptomatic solutions rather than addressing the institutions that cause challenges in the entrepreneurial ecosystem. Our study is also of great practical relevance, as Western European policy makers and incubator managers can use our study to help start-ups overcome their major challenges. Next, we discuss the components of the entrepreneurial ecosystem and the support provided by incubators. We then present two empirical studies: one in which we identify challenges, and one in which we identify practices. We end our paper with a brief discussion and conclusion.

\section{Background}

We begin this section by discussing the literature on entrepreneurial ecosystems. This literature will guide our empirical analysis by enabling us to identify those components that are underdeveloped in Europe and that thereby constrain start-up activity. We then discuss the incubator's role in the entrepreneurial ecosystem.

\subsection{Entrepreneurial ecosystems}

Over the past 5 years, literature on entrepreneurial ecosystems has emerged to explain the presence or absence of start-up activity in a geographical area. Its focus on the role of the start-up's environment makes the literature on entrepreneurial ecosystems similar to that on clusters or innovation systems (Ács et al. 2014). However, the entrepreneurial ecosystem literature is unique in the sense that it points at components in the environment that are particularly important for start-ups rather than firms in general (Spigel 2015). Accordingly, the entrepreneurial ecosystem consists of a set of interdependent components that exist outside the start-up that contribute to the start-up's success (Spigel 2015; Stam 2015). Entrepreneurial ecosystems are not only shaped through top-down policies, but

1 'Western Europe' consists of Austria, Belgium, France, Germany, Liechtenstein, Luxembourg, Monaco, the Netherlands and Switzerland (United Nations Statistics Division 2015). 
primarily through bottom up activities involving a broad range of interdependent governmental and non-governmental actors (Feld 2012; Stam 2015). If components in the entrepreneurial ecosystem are underdeveloped, start-ups may face challenges that constrain their growth. The increasing interest in entrepreneurial ecosystems has led to the identification of a variety of components that are deemed to be important for a thriving ecosystem (see e.g. Cohen 2006; Feld 2012; Neck et al. 2004; Spigel 2015; Stam 2015; WEF 2013). In discussing the most cited components, we follow literature on innovation systems to broadly group these components into three categories: actors, networks and institutions (Carlsson and Stankiewicz 1991; Hekkert et al. 2007; Van Rijnsoever et al. 2015).

There are various actors who can strengthen the entrepreneurial ecosystem by providing resources that are necessary for startups to thrive and by shaping the ecosystem's institutions. First, the ecosystem should have a talent pool of individuals with high level of human capital, which includes both technical and entrepreneurial skills (Feld 2012; Florida et al. 2008). These individuals act as start-up founders or employees (Neck et al. 2004). Second, domestic and foreign markets, consisting of consumers and businesses who act as customers, should be accessible and large enough for start-ups to be able to sell their products or services (WEF 2013). Third, financial capital, provided by private investors or public funding agencies, enable start-ups to obtain the necessary resources for their founding and growth (Cohen 2006; Neck et al. 2004). Fourth, support services can provide start-ups to obtain specialized knowledge (Spigel 2015). These services are primarily provided by mentors (experienced entrepreneurs who advice young founders), professional service providers (e.g. lawyers, accountants or consultants), and incubators (that we discuss in more detail in the next section). Fifth, universities may play a catalyzing role. Universities contribute to the ecosystem's human capital by providing well-educated entrepreneurs and employees as well as faculty staff that may act as consultants to start-up companies. Further, their expertise may lead to technological opportunities based on which start-ups can build their products, and they are important in fostering a culture of innovation and entrepreneurship (Etzkowitz 2004; Neck et al. 2004; Stam 2015). Finally, both public and private actors can contribute to the ecosystem's physical infrastructure. This infrastructure provides start-ups with the required tangible resources, including office space, telecommunication facilities and transportation infrastructure (Spigel 2015).

The presence of these actors alone is insufficient for entrepreneurial ecosystems to be successful. Actors should be connected through various formal and informal networks (Neck et al. 2004) that facilitate the flow of resources between them (Spigel 2015). Networks of actors in the entrepreneurial ecosystem operate under an institutional environment that supports or constraints start-ups. Institutions are the socially constructed 'rules of the game' that structure the actions of actors in the entrepreneurial ecosystem (North 1990; Pacheco et al. 2010; Scott 1995). The entrepreneurial ecosystem literature primarily points at the ecosystem's regulation and culture as the two most important institutions that influence start-up activity (Neck et al. 2004; Spigel 2015; Stam 2015). Governments can create the optimal conditions for innovation and entrepreneurship to flourish, for example by ensuring low levels of corruption, a high quality educational system and adequate intellectual property protection (Casper and Soskice 2004). In addition, governments can provide regulatory institutions that are specifically aimed at stimulating start-ups, including start-up subsidies or incentives to support R\&D collaboration between start-ups and universities (Goldfarb and Henrekson 2003; van Rijnsoever et al. 2014). The ecosystem's culture should encourage entrepreneurship as a career path, it should ensure that (nascent) entrepreneurs think in terms of the market where they want to sell their products, it should 
make risk taking socially accepted, and it should celebrate successful local start-ups (Spigel 2015; WEF 2013).

\subsection{Incubators in the entrepreneurial ecosystem}

Incubators can strengthen the entrepreneurial ecosystem by supporting local start-ups. Since their widespread diffusion in the 1980s, the incubator's value offering has developed considerably (Bruneel et al. 2012; Mian 2014), which reflects their changing role in the entrepreneurial ecosystem. Accordingly, incubators support start-ups in various ways.

First, as part of the ecosystem's support services (Spigel 2015; Stam 2015), incubators provide start-ups with direct access to several ancillary resources and services. Initially, the 'first generation' incubators focused on providing start-ups with shared office space and other tangible resources, such as meeting rooms, to create economies of scale (Barrow 2001; Bruneel et al. 2012). More specialized (e.g. university-affiliated) incubators also provided access to equipment or laboratories (Mian 1997). From the early 1990s, incubators increasingly focused on supporting technology based start-ups (Ahmad and Ingle 2013; Bruneel et al. 2012). Incubators realized that founders of these start-ups lacked entrepreneurial experience, which led incubators to expand their service portfolio (Bruneel et al. 2012). Incubators started providing professional consultancy services, as well as coaching and training for entrepreneurs, primarily as a way for entrepreneurs to develop missing business knowledge (Rice 2002). These incubators also started to provide financial capital by investing in their tenant companies (Aerts et al. 2007; Barrow 2001).

Second, by curating the relationship between entrepreneurs and their peers, or between entrepreneurs and other actors in the entrepreneurial ecosystem incubators act as a node in the entrepreneurial ecosystem (Bergek and Norrman 2008; Spigel 2015). This was the focus of the 'third generation' incubators, which emerged in the late 1990s and aimed to facilitate access to external resources and networks (Bøllingtoft and Ulhøi 2005; Hansen et al. 2000). These incubators stimulated start-ups to interact with each other in the incubator's 'community', by co-locating start-ups in the incubator's premises, by creating synergies among start-ups through the incubator's selection process, by organizing network events, and by acting as relational 'brokers' to make one-on-one connections (Cooper et al. 2010; Hughes et al. 2007; Totterman and Sten 2005). The incubator thereby creates a dense network of start-ups that are willing to help each other by engaging in collaborative projects or by exchanging knowledge and networks (Mcadam and Marlow 2007; Totterman and Sten 2005). Facilitating such network density leads to greater visibility of startups in the entrepreneurial ecosystem, which makes it easier for start-ups to connect to external actors. Incubators further facilitate such access to external networks by organizing events, by establishing partnerships with for example investors or universities, or by leveraging the personal networks of incubator managers and mentors (Hansen et al. 2000; Patton and Marlow 2011).

Third, incubators can help start-ups to cope with the institutions of the entrepreneurial ecosystem. They may do so by acting as a 'safe harbor' that protects start-ups from unfavorable institutions (Amezcua et al. 2013; Hackett and Dilts 2004b). For example, the incubator's community creates a culture of support and encouragement (Cooper et al. 2010), which may compensate for the absence of such a culture in the entrepreneurial ecosystem. Start-ups in the incubator may also benefit from the added credibility that incubators bring, as acceptance into the incubator acts as a 'stamp of approval' to potential collaborators (NESTA 2011). This contributes to the start-up's legitimacy, which may be particularly valuable in ecosystems where founding a start-up is perceived to deviate from 
the dominant cultural norms and values. In addition to protecting start-ups from unfavorable institutions, incubators may also act as 'institutional entrepreneurs' (Amezcua et al. 2013); actors who transform or create institutions that favor their interests (DiMaggio 1988). For example, by organizing a collective group of start-ups, the incubator increases the power and legitimacy of the individual start-ups (Pacheco et al. 2010), which may enable incubators to negotiate favorable regulations. As an institutional entrepreneur, the incubator no longer only impacts individual start-ups, but has the potential to improve the institutions of the entrepreneurial ecosystem as a whole.

\section{Methods study 1}

\subsection{Research design and case selection}

To explore the challenges of Western European start-ups, we conducted 90 semi-structured interviews with entrepreneurs, incubator managers and other key stakeholders in the entrepreneurial ecosystem, such as investors, university technology transfer officers, mentors and policy makers ${ }^{2}$ in Western European countries. Our sample consists of 13 incubators, six of which were part of the Climate Knowledge and Innovation Community (Climate-KIC), a European initiative to stimulate clean tech innovation and entrepreneurship. These university-affiliated incubators were located in the Netherlands (3), France (1), Switzerland (1) and Germany (1). Although Climate-KIC focuses on supporting clean tech start-ups, these six incubators were active in a wide variety of industries. To complement our sample, we included insights from seven non-university affiliated incubators located in Germany (5) and the Netherlands (2). These incubators were approached through events, desk research and existing network contacts. The final sample of 13 incubators allows for comparison while maintaining a high level of variation, which contributes to the reliability and generalizability of our findings. The sample is homogeneous in the sense that all incubators focused on supporting early stage start-ups, which we defined as new ventures where technical know-how is capitalized and exploited through new products and services (Bergek and Norrman 2015; Trimi and BerbegalMirabent 2012). Further, rather than solely focusing on one type of support (e.g. coworking spaces that only provide office space, or educational programs that only provide mentorship) the incubators in our sample supported these start-ups with a comprehensive range of services. Within these constraints, we maximized variation. This is particularly important when the population under study is heterogeneous, as is the case with incubators (Aernoudt 2004; Bergek and Norrman 2008). Our sample reflects this variety as it includes incubators in different industries (e.g. software, clean tech, life sciences), with different founding partners (e.g. universities, investors, municipalities), operating both for profit and non-profit. The diversity of the interviewees as well as the relatively large number of interviews that we conducted contributes to the reliability of our findings, as it enabled us to triangulate our findings in an early stage, thereby minimizing the influence of interviewees' individual bias and (mis)perceptions (Bryman 2008).

We were not able to conduct interviews in the Western European countries of Austria, Belgium, Liechtenstein, Luxembourg and Monaco. However, the nine Western European countries are very similar in for example their regulatory framework and entrepreneurial

2 The interview data from the six university-affiliated incubators was also used in a prior study on incubator strategies (van Weele et al. 2016). 
attitudes and are therefore often grouped in the same categories in for example the Global Entrepreneurship Monitor and the literature on Varieties of Capitalism (Hall and Soskice 2001; Kelley et al. 2012). Further, among the interviewees were several European policy makers, as well as entrepreneurs that were active in multiple European countries, and incubator managers and investors overseeing an international portfolio of start-ups. The international background of these interviewees compensated for the limited number of European countries in which interviews were conducted. We are therefore confident that the challenges that we identify are relevant to Western Europe as a whole.

\subsection{Data collection and data analysis}

Interviewees were approached through the network of Climate-KIC, through the researchers' personal networks, through desk research and by asking interviewees to introduce the researcher to other interesting actors for this research. All interviews were conducted between January 2012 and May 2015. Conducting interviews on-site enabled us to augment the dataset with observations and informal conversations. Table 1 below provides an overview of the interviewees per category and country. In addition, we attended various start-up events and formal meetings organized by Climate-KIC during which challenges and solutions for European (clean tech) entrepreneurship were discussed. This enabled us to triangulate our findings and to enrich our interviews.

The interviews took $40 \mathrm{~min}$, on average. During the interviews, we wanted to "follow wherever the informants lead us in the investigation of our guiding research question" (Gioia et al. 2012 p. 20). We therefore conducted semi-structured interviews with a common set of questions, while allowing interviewees to elaborate on their answers and enabling us to ask additional probing questions. Accordingly, the list of questions as provided in Appendices 1 and 2 should not be interpreted as a strict interview protocol, but as a broad set of questions that guided the interviews. Every interview started with a brief introduction of the research goal. We then asked interviewees to describe their personal background as well as the background of their start-up or incubator. Given our aim of identifying challenges faced by start-ups, we then asked interviewees to discuss what they perceived as the strengths and weaknesses of their particular region or country in terms of starting a business. This discussion formed the core of the interviews. Many interviewees had an international background, and we asked them to compare the different entrepreneurial ecosystems in which they had lived to each other. In this part of the interview, the concepts of the entrepreneurial ecosystem literature acted as 'sensitizing concepts' (Blumer 1954) that guided us to ask probing question about specific components of the

Table 1 Interviews conducted for study 1

\begin{tabular}{lcclr}
\hline & Entrepreneurs & Incubator staff & $\begin{array}{l}\text { Other (e.g. investors, } \\
\text { policy makers, university } \\
\text { representatives) }\end{array}$ & Total \\
\hline Netherlands & 24 & 13 & 12 & 49 \\
Switzerland & 8 & 1 & 2 & 11 \\
France & 8 & 2 & 0 & 10 \\
Germany & 12 & 6 & 2 & 20 \\
Total & 52 & 23 & 15 & 90 \\
\hline
\end{tabular}


entrepreneurial ecosystem (e.g. to what extent did you feel supported by your university when founding this start-up? What forms of start-up capital are available?). Initially, we relied on open questions to identify general challenges. As the study evolved, we included more specific questions to explore particular challenges in greater detail. In the case of incubated entrepreneurs and incubator staff, we also asked about what forms of support were provided by the incubators.

If possible, the interviews were recorded and transcribed. Data was collected until no new relevant topics emerged, which suggests that theoretical saturation was reached. Data was analyzed by coding the interviews using the qualitative data analysis program Nvivo. As a qualitative, inductive study, our coding was a highly iterative process. Still, it roughly proceeded in three phases. During the initial stage of coding, we labelled segments of interview scripts with codes that were based on interviewees' own words. For example the segment "the skills that you need as an entrepreneur: presenting, networking, etc., they don't teach these at a university" was labelled as 'universities do not teach entrepreneurial skills'. Using such 'in vivo' codes minimizes researcher subjectivity and bias (Gioia et al. 2012). In the second phase of coding, we combined in vivo codes into broader categories. Again, the literature on entrepreneurial ecosystems guided our analysis as they provided a general sense of what to look for. For example, codes that were related to universities (e.g. 'universities do not teach entrepreneurial skills', 'universities lack entrepreneurial culture', 'difficult to negotiate IP with universities') were combined into a higher level code that was labelled 'universities are not focused on entrepreneurship'. These higher level codes eventually formed the core concepts of this study: the challenges faced by Western European start-ups. Given that the components of entrepreneurial ecosystems are interdependent, the third phase of coding consisted of 'axial coding' (Corbin and Strauss 1990) to explore relationships among codes. This eventually enabled us to create a schematic overview of how the challenges are connected and potentially re-inforce each other.

\section{Findings study 1}

We now discuss the main challenges faced by Western European start-ups, by focusing on those components in the entrepreneurial ecosystem that interviewees felt were underdeveloped. In doing so, we focus on those challenges that were consistently identified over almost all countries in our sample. Appendix 3 provides additional supporting material for these challenges to confirm that each challenge was observed in each country.

\subsection{Lack of market orientation}

The entrepreneurs in the incubators typically had a strong technological background, but the interviews showed that most entrepreneurs were unfamiliar with activities related to managing and growing their business such as presenting to investors, reaching out to customers or managing employees. A Dutch incubator manager said: "Selling their product, being able to clearly communicate their value proposition, that's a thing that a lot of entrepreneurs struggle with". Entrepreneurs were seen to underestimate the importance of fulfilling a customer need and were thus struggling to create a scalable business around their idea. One of the Swiss incubator managers said: "There has to be a strong market focus. A lot of ideas we get, people think only from the product itself, like a researcher or so who hasn't thought of customers at all". This lack of market orientation was partly seen as the result from education systems in Europe, which pay little attention to the 
development of entrepreneurial skills and a practical and commercial mindset. In addition, one of the interviewees said that Europeans are inherently modest and not as good as 'sales people' as Americans. Accordingly, this challenge is primarily rooted in cultural European institutions that are not easily changed.

\subsection{Lack of an entrepreneurial culture}

Related to this, interviewees found that the culture of Western European countries does not encourage entrepreneurship. This challenge has also been recognized by the European Commission (European Commission 2013). Entrepreneurs felt that entrepreneurship is perceived as a high risk career choice, and that their social environment was skeptic towards their aspirations to start a business. An entrepreneur illustrated: "they give me so much credits for having the courage to take this risk". Interviewees also found that failure is not socially accepted and they were concerned about stringent bankruptcy laws. These formal and informal institutions contribute to a high fear of failure among entrepreneurs, they may inhibit entrepreneurial initiatives and they may temper ambitions of entrepreneurs. Investors and incubators found that those start-ups that do exist have limited ambitions for growth, as entrepreneurs were primarily motivated by a desire to be their own boss instead of aspiring to create a large company. One of the investors said: "It's all about the entrepreneurial drive: what is your goal? Where do you want to go? Many entrepreneurs are happy when they have one or two customers ... They're playing it safe".

\subsection{Small domestic market}

Compared to US or Asian markets, the individual European countries have relatively small domestic markets, and the larger European market is fragmented. This problem has been recognized before (Bravo-biosca 2011). However, despite policy makers' efforts to unify the European markets (European Commission 2013), foreign markets, even within Europe, remain difficult to access. Interviewees perceived the European market to be fragmented, as countries differ from one another in terms of language, regulations, customer preferences, etc. These institutional differences make it difficult for start-ups to capture the entire European market. While start-ups offering similar products or services may co-exist in different European countries, it is difficult for start-ups to scale their activities. The small domestic markets can partly explain the limited ambitions for growth of European entrepreneurs. As one Dutch investor and former entrepreneur illustrated, European startups think local instead of global: "Our goal was to attract 100,000 users. Which is a lot by Dutch standards, but nothing from an international point of view. The problem is that you're not thinking big, and we made some wrong choice because of that".

\subsection{Lack of early stage capital}

Europe's lack of financial capital for start-ups is well-documented (Bottazzi and Da Rin 2002; Philippon and Véron 2008) and was also identified as a challenge by interviewees in our sample. Interviewees felt that 'seed funding', a relatively small amount of funding to get the company started, was relatively easy to obtain. However, entrepreneurs felt that only a small number of investors were willing to provide 'early stage capital', larger amounts of additional funding necessary to develop a proof of concept and to scale marketing activities. A German incubator manager said: "it's very rare that very big investments are made in Berlin or Germany. There are a lot of smaller investments and lot 
of angel investors, but it seems to be very hard to larger get investments here". Again, this makes it difficult to scale start-ups. As an explanation, multiple institutional causes were mentioned. First, investors found it unattractive to invest in start-ups due to Europe's fragmented market and because start-ups lacked an experienced management team and a strong market focus. Second, entrepreneurs found investors to be risk averse, as they preferred to invest in real estate or family owned, low tech businesses. Third, the motivations of European entrepreneurs to be their own boss makes them hesitant to give up equity to investors (Audretsch et al. 2002; Fiedler and Hellmann 2001). This was illustrated by one of the entrepreneurs who said: "I don't want anyone to interfere. (...) I want to be the one in charge. That is my main concern".

\subsection{Universities are not focused on entrepreneurship}

European universities were perceived to fulfill their role as catalysts in the entrepreneurial ecosystem only to a limited extent. A manager of a university affiliated incubator in the Netherlands said: "there are cultural and institutional causes for this, but no, there's not an entrepreneurial culture. That doesn't mean that people don't do it [founding a start-up], but it's definitely not stimulated". Although research and education at European universities were perceived to be of high quality, interviewees said that it was difficult to create start-ups based on university research, as the basic research conducted by universities is not ready for commercialization. Start-ups also struggled to access university equipment and entrepreneurs felt that university technology transfer offices had little experience with start-ups, constraining the transfer of knowledge from universities to start-ups. Thereby, entrepreneurs were unable to access cutting-edge knowledge and technology that can form the basis of high-tech firms with a competitive advantage (Grant 1996; McEvily and Chakravarthy 2002). Finally, in line with Wilson (2008), we found entrepreneurship education at universities to be rare, and poorly integrated in the university's curriculum. Interviewees found that universities neglected entrepreneurship as a career choice and prepared students for careers in government, multinationals or universities instead. Some universities organized standalone courses in which students developed entrepreneurial skills, such as writing a business plan. However, these courses were not focused on creating technology-based start-ups with a high growth potential. Universities thereby lack a culture of ambitious entrepreneurship. When discussing the university's culture and curriculum, one student entrepreneur said: "You're expected to pursue a career at a big multinational or to start a PhD. Entrepreneurship is just not an option (...) The skills that you need as an entrepreneur: presenting, networking, etc., they don't teach these at a university". The institutional cause of this challenge is the strong incentive for universities to pursue academic research rather than to collaborate with industry or to commercialize knowledge (Goldfarb and Henrekson 2003).

Figure 1 provides a conceptual overview of the challenges that we identified. Overall, it seems that the main problem in Western Europe is not the unwillingness or inability of entrepreneurs to found start-ups. Rather, the lack of market orientation, ambition and resources (e.g. access to large markets and capital) constraints the ability of existing startups to grow. One Dutch incubator manager illustrated this as follows: "Most start-ups are able to achieve some small successes: to think of a good idea, to attract some subsidies, to find a launching customer... But they fail to make it out of that stage to experience real growth". Consequently, the image emerges that the overarching challenge is for start-ups to grow into successful businesses. This creates a reinforcing, vicious cycle, as there are few successful entrepreneurs who could serve as inspiring role models or as angel 


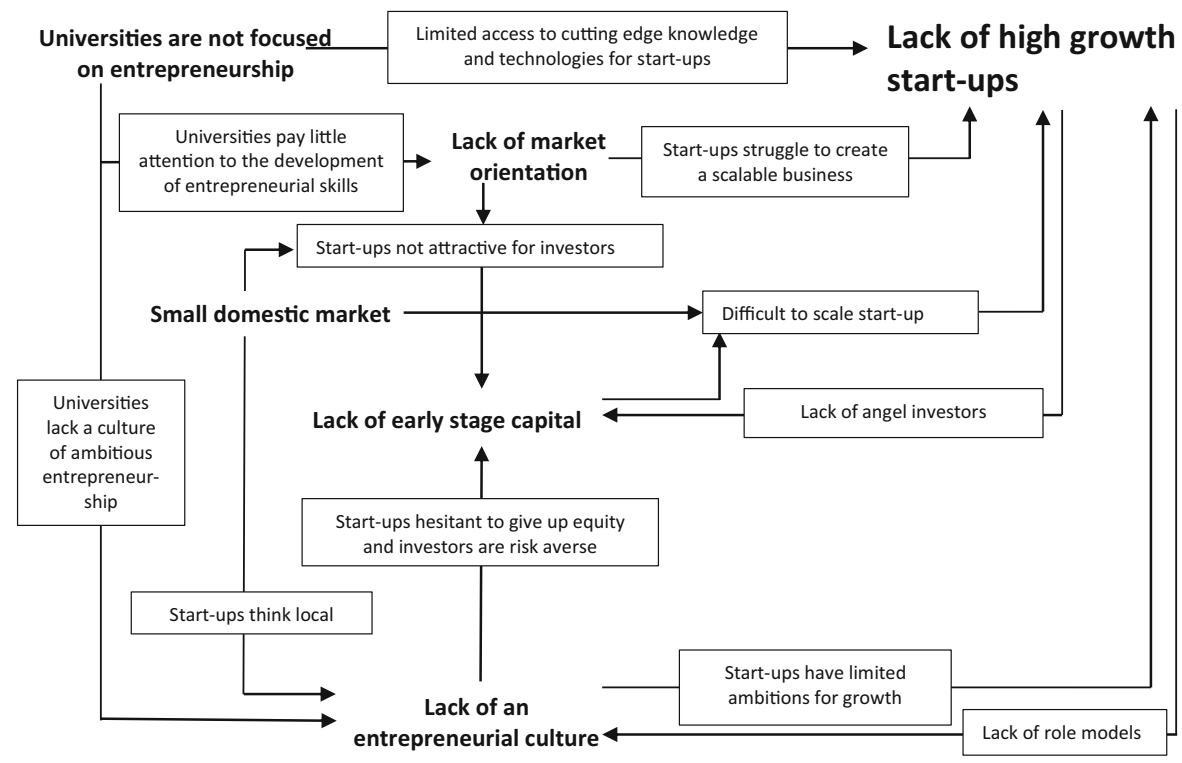

Fig. 1 Challenges faced by Western European start-ups

investors' who invest in a new generation of start-ups. The challenges identified all have institutional roots in European culture, norms and regulations, which makes it difficult to overcome them.

The severity of the challenges will likely differ across countries: the small domestic market challenge, for example, will likely be more severe for start-ups in the Netherlands than in France or Germany. We also note that the five challenges were not the only challenges that interviewees identified. For example, interviewees in France also perceived the bureaucratic procedures for starting and operating a business as an important challenge, and German interviewees felt that many local start-ups lacked innovative ideas as they mostly copied and improved existing business models and ideas. Still, given that the aforementioned five challenges were consistently identified by interviewees in all countries, they form a good starting point for exploring incubation practices. Further, these five challenges are similar to those identified by more generic studies on European innovation and entrepreneurship (see e.g. Kelley et al. 2012; Philippon and Véron 2008; Schneider and Veugelers 2010; Tijssen and van Wijk 1999), and are also in line with recent European policies to support start-ups, such as the Entrepreneurship 2020 action plan and the Start-up Europe Partnership, (European Commission 2013, 2014). This further validates our findings.

\section{Methods study 2}

\subsection{Research design and case selection}

Next, we conducted a multi-case study in which we studied start-ups and incubators in various entrepreneurial ecosystems. We used a theoretical sampling strategy to identify a 
specific case (i.e. a specific region or country) that would be likely to provide useful practices for every challenge identified in study $1 .^{3}$ These ecosystems are, similar to Western Europe, innovation driven economies (Kelley et al. 2012) that stimulate entrepreneurship to achieve economic growth. Our sampling strategy resulted in the following four cases:

\subsubsection{Silicon Valley}

We use Silicon Valley as a case study to identify incubation practices through which incubators make start-ups more market oriented, as Silicon Valley has the most developed entrepreneurial ecosystem and also the most mature and developed incubators (Aernoudt 2004; Herrmann et al. 2012). Consequently, Silicon Valley entrepreneurs and incubators are famous for their ability to translate technological ideas into successful, high-growth start-ups, and Silicon Valley is therefore a suitable case study. Data was collected between February and July 2013.

\subsubsection{Australia}

We study start-ups in Australia to gain further insights on how start-ups are able to thrive in a country lacking an entrepreneurial culture. Although Australia has a rich history of small businesses, it also has a high fear of failure (Kelley et al. 2012) and the lack of an entrepreneurial culture has been recognized to constrain the development of technology based start-ups (PWC and Google 2013). Data was collected in Sydney, Melbourne and Canberra between February and July 2013.

\subsubsection{Israel}

To identify incubation practices that enable start-ups to overcome a small domestic market we look at Israel. This country has a small domestic market that is isolated from foreign markets. However, this challenge has not stopped Israel from becoming a 'start-up nation' with Israeli start-ups having a global impact (Senor and Singer 2009). Data was collected in the high-tech regions of Tel Aviv and Haifa between May and July 2014.

\subsubsection{The greater Boston area}

To identify incubation practices that facilitate the relationship between start-ups and universities we study the greater Boston area, which is the metropolitan area surrounding the city of Boston that covers cities such as Somerville and Cambridge. This area is not only home to many top-tier research institutes, but also to many start-ups in a variety of industries, such as IT, clean tech and life sciences. Data was collected between February and July 2014.

\footnotetext{
3 Although we connected every individual case to a specific challenge, we also derived incubation practices from other cases. For the lack of early stage funding, we did not include a specific case, but identified incubation practices across all four cases. The Australian interview data was also used for a study on start-up communities (van Weele et al. 2014).
} 


\subsection{Data collection and data analysis}

The authors visited the countries between 2 and 6 months, which enabled them to be submerged in the local entrepreneurial ecosystem to gain in-depth insights. For all countries, the second author assisted in data collection to discuss and interpret findings and to ensure a consistent and valid process of data collection and analysis. Similar to study 1 , interviews were the primary data source, and we interviewed a similar group of entrepreneurs, incubator representatives and other stakeholders. In addition to incubators we studied related programs that aim to facilitate entrepreneurship, such as co-working spaces, university entrepreneurship programs and national entrepreneurship policies. Table 2 below provides a detailed breakdown of the number of interviews per category. We collected data on a total of 34 incubators (and related start-up programs) in Silicon Valley (6), Australia (11), Israel (10) and the greater Boston area (7). Similar to study 1, we aimed to have a diverse rather than a representative sample to identify a variety of practices. Interviewees were identified and approached through desk research, by attending events and by asking interviewees to make introductions to other interesting individuals after the interviews.

Again, the interviews were semi-structured, and the same set of guiding questions was used as for study 1 . We explored the strengths and weaknesses of the entrepreneurial ecosystem in a similar way as we did for study 1 . Then, because we aimed to identify incubation practices, the support provided by the incubator was discussed in more detail. We asked incubator representatives about how they support start-ups, and we asked entrepreneurs what forms of support they receive, how, and when. In doing so, we asked case specific questions based on the country focus as outlined in Sect. 5.1 (e.g. "how does your incubator enable start-ups to overcome Israel's small domestic market?"). The literature on incubators guided us here, by enabling us to ask probing questions about forms of support that the interviewee might have missed (e.g. "what is the role of the incubator's community in connecting to international markets?"). Similar to how the questionnaire of study 1 evolved, we began by asking general questions about the incubator's support. In later stages, we focused more explicitly on particular incubation practices to understand them in greater detail.

Interviews were recorded, transcribed and analyzed with Nvivo in a similar manner as in study 1 . We started the coding process by staying close to the interviewees' own words. We then categorized similar codes into broader categories that formed the incubation practices. Again, data was collected until theoretical saturation was reached and no new concepts emerged. Then, for every case, detailed country reports were written to create an in-depth understanding of the entrepreneurial ecosystem and incubation practices for every individual case. The final phase of data analysis consisted of a cross case comparison, in

Table 2 Interviews conducted for study 2

\begin{tabular}{lcclr}
\hline & Entrepreneurs & $\begin{array}{l}\text { Incubator staff and } \\
\text { other facilitators }\end{array}$ & $\begin{array}{l}\text { Other (e.g. investors, } \\
\text { policy makers, university } \\
\text { staff) }\end{array}$ & Total \\
\hline Silicon Valley & 60 & 7 & 4 & 71 \\
Israel & 11 & 11 & 9 & 31 \\
Australia & 28 & 20 & 5 & 53 \\
Greater Boston & 12 & 7 & 17 & 36 \\
Total & 111 & 45 & 35 & 191 \\
\hline
\end{tabular}


which we related the various incubation practices to the challenges faced by Western European start-ups.

\section{Findings study 2}

We now discuss how incubators in Silicon Valley, Australia, Israel and the greater Boston area can help start-ups in overcoming the challenges that we identified in study 1 . In doing so, we also relate the incubation practices to the institutions that are at the heart of these challenges. Table 3 provides an overview of the incubation practices.

\subsection{Lack of market orientation}

Incubators used a variety of practices to make start-ups more market oriented:

\subsubsection{Push for interaction with customers}

Inspired by the lean start-up method (Blank 2013; Ries 2011), incubators encouraged startups to engage with customers in order to identify customer needs. Some incubators

Table 3 Incubation practices

\begin{tabular}{|c|c|c|c|c|c|}
\hline Challenges and practices & Europe & $\begin{array}{l}\text { Silicon } \\
\text { valley }\end{array}$ & Australia & Israel & Boston \\
\hline
\end{tabular}

1 Lack of market orientation

Push for interaction with customers

Provide mentorship

Provide small amounts of funding

Facilitate outsourcing

$\begin{array}{ll}X & X \\ X & X \\ & X\end{array}$

$\mathrm{X}$

X X

$x$

2 Lack of an entrepreneurial culture

Organize start-up tours

Create a supportive community

Create a healthy competition among start-ups

$\begin{array}{ll}X & X \\ X\end{array}$

$\mathrm{X}$

3 Small domestic market

Create an international community

Create international partnerships

$\mathrm{X}$

Enable a soft landing in foreign ecosystems

4 Lack of early stage capital

Selectively connect start-ups to funding sources

Enable start-ups to be capital efficient

Create a separate joint fund

5 Universities are not focused on entrepreneurship

Provide access to technical expertise and equipment

Mediate in internships

X

Complement university curriculum

$\mathrm{X}$

Create a student board

$\mathrm{X}$

An ' $\mathrm{X}$ ' signals that a particular incubation practice was identified in a particular entrepreneurial ecosystem 
informally encouraged start-ups to do so through mentors who emphasized the importance of such 'customer development'. One of the Silicon Valley incubators had a formal requirement that every start-up should talk to at least 100 customers during their stay in the incubator.

\subsubsection{Provide mentorship}

One of the incubator managers said that start-ups develop parameters or boundaries around their idea that result in implicit assumptions about their product or market. These assumptions may constrain the search for a suitable target market when they become taken for granted assumptions that are not questioned during daily operations. During "tough" and "stressful" one on one sessions, mentors forced entrepreneurs to explicate and challenge these underlying assumptions, making entrepreneurs re-evaluate their start-up: "It's not that they tell you you're wrong, they'll ... push back. Sometimes you need somebody to not assume everything you say. That was very useful". These mentors were typically experienced entrepreneurs who had started multiple businesses in the past and were seen to have the necessary credibility to make entrepreneurs re-evaluate their technology or business model.

\subsubsection{Provide small amounts of funding}

To find a viable business model, one of the more prominent Silicon Valley incubators promoted an iterative development process in which start-ups continuously adjusted their product or idea based on the feedback of the market (being customers and investors). This incubator was skeptic of providing start-ups with too much money, as this eliminates the market pressures that force start-ups to iterate on their business model: "If you give too much money in the beginning, good founders can work on bad ideas for too long". Accordingly, the incubator only provided a small amount of funding, just enough to cover the founders' living expenses during the duration of the incubator program.

\subsubsection{Facilitate outsourcing}

Given the limited entrepreneurial experience of entrepreneurs, they struggled to get acquainted with the various aspects of setting up a company, such as incorporating the company or filing for taxes. Instead of developing these skills in-house, the incubator enabled start-ups to outsource these unfamiliar activities. We found incubators to provide a wide range of in-house services, such as design, legal, or human resources. This enables start-ups to focus on developing their product and finding a market application: "At this incubator you're only supposed to do two things: talk to your users and develop your product".

All but the third practice are focused on networks, as incubators connect start-ups to each other, to mentors or to external networks. These practices primarily aim to help startups find a target market and to accelerate their development. They do not change the underlying cultural institutions that cause start-ups to be insufficiently market-oriented. The practices raise questions about the tendency of European incubators to be founded and supported by governments and universities (Aerts et al. 2007; Barbero et al. 2012). The practices suggest that, to make start-ups more market-oriented, incubators need be more market-oriented as well. One way to do so is by relying more on private instead of public 
funding. Further, mentors and incubator staff require entrepreneurial experience to be credible. However, interviewees found that European incubator staff often had a policy or academic background. A French entrepreneur illustrated: "We were in contact with the university. In which there are some coaches. But it was all ********. They have no idea what was the reality in the field. So it is really important to have people that have been in a startup. That have the experience".

\subsection{Lack of an entrepreneurial culture}

Incubators can use several practices to create a culture of entrepreneurship and ambition.

\subsubsection{Organize start-up tours}

Some Israeli and Australian incubators organized a start-up tour to foreign ecosystems such as Silicon Valley. These start-up tours aimed to expose start-ups to the cultural values of a different entrepreneurial ecosystem, by connecting them to start-ups and other stakeholders abroad, rather than changing the culture of the domestic entrepreneurial ecosystem. Some entrepreneurs explained that they were "inspired" by the ambitious Silicon Valley startups, taking that mindset back home: "Getting that mindset of how things operate down in the Valley. And adopting that to our... Not only to our business, but to ourselves".

\subsubsection{Create a supportive community}

The community of start-ups in an incubator forms a group of likeminded individuals that entrepreneurs can identify with. These communities created a shared 'sense of belonging', and provided motivation and comfort as entrepreneurs saw other start-ups going through similar challenges: "It shows that things are not easy, and everyone has these issues that they go through ... Hearing their struggles makes you feel like "o, we're not doing so badly". Selectively admitting start-ups to the community was seen as important. Some of these communities had a selection process to decide who could join. Being accepted into the community provided motivation and confidence that helped entrepreneurs to justify their aspirations to their social environment. As one Australian entrepreneur illustrated: "It makes me confident that I got picked by these twenty people ... I might fail ... but people can't tell me I was a fool, because I was picked".

\subsubsection{Create a healthy competition among start-ups}

The incubator's community contributed to a "healthy competition" between start-ups, as start-ups were inspired by the positive results of others, and aspired to achieve similar success. One entrepreneur said: "You don't want to be the only team that did not get funded". This culture of peer pressure stimulated entrepreneurs to push themselves and to set their ambitions higher. This culture can be stimulated by organizing weekly meetings during which entrepreneurs were encouraged to show each other their progress. These meetings "pushed people to finish things in order to show them off". One of the Australian incubator managers said: "we have a Monday morning meeting. Everybody has a "no fail goal' that you have to achieve. You don't want to be the guy that says "no, we didn't achieve our goal this week". 
The above practices are all focused on encouraging interaction between start-ups. By doing so, the incubators create its own culture that encourages risk taking and ambitious thinking. The incubator thereby becomes a 'safe haven' for start-ups, rather than addressing the culture in the broader entrepreneurial ecosystem. An Australian incubator manager illustrated this as follows: "I think [entrepreneurs] need a place like this because it gives them a safe place to experiment, which is free from the negative Australian cultural traits". Incubators emphasized that it is important to only select high quality entrepreneurs, as this contributes to the healthy competition and inspiring culture in the incubator's community.

\subsection{Small domestic market}

Incubators can use various practices to enable start-ups to overcome the small domestic market constraint by facilitating the expansion into foreign markets.

\subsubsection{Create an international community}

Israeli incubator managers emphasized the importance of having a mix of international teams in the incubator's community. This encouraged all start-ups to "think big" and to have a "global mindset"; to use English in communications, and to see their start-up as a potentially global business.

\subsubsection{Create international partnerships}

Incubators in all countries relied on their external network to connect entrepreneurs to foreign customers, thereby compensating for the start-up's lack of international networks. One Israeli incubator manager said that only providing introductions is insufficient, as start-ups suffer from a 'knowledge gap': start-ups were unaware of cultural differences between countries, and they did not always appreciate that foreign customers or investors may value the start-up's services differently. Consequently, to sell their products in foreign markets, start-ups first needed to gain in-depth understanding of these foreign markets. This incubator created structural and ongoing partnerships with foreign corporates that enabled start-ups to do so: "we realized that there were more pieces missing, and it led us to understand the need to bring in these organizations as partners, and not just introduce the start-ups to them".

\subsubsection{Enable a soft landing in foreign ecosystems}

One of the Israeli incubators had their main office in Silicon Valley at which the entire incubator program took place. Entrepreneurs were provided with office space, and, more importantly, with advice and guidance on local regulations and customs. The incubator thereby enabled Israeli start-ups to have a "soft landing" in Silicon Valley, facilitating the transition towards a different ecosystem and providing access to a larger market. The incubator encouraged start-ups to have their sales office in Silicon Valley, while continuing $\mathrm{R} \& \mathrm{D}$ in Israel. This enabled start-ups to be 'immersed in the market', creating a deep understanding of local rules, norms and institutions.

One Silicon Valley incubator manager said: "a strategy that is successful in their home country is not necessarily successful here. The rules of the game are different". Through 
the above practices, incubators enable start-ups to understand institutional differences across countries by creating relationships with local customers and investors. Incubators provide guidance on where to adjust the start-up's strategy to ensure a fit with the local context, thereby enhancing the growth potential of the start-up. However, the incubator facilitates the transition to a different market environment without addressing the institutions that inhibit this transition itself.

\subsection{Lack of early stage capital}

We found incubators to use various practices to help start-ups overcome the lack of early stage capital.

\subsubsection{Selectively connect start-ups to funding sources}

With some incubators having an acceptance rate as low as five per cent, the incubator acted as a quality filter to investors: "It's the ability to distinguish themselves in the crowd ... [Investors know that] you've been screened, you've been trained, and you've already made it past these first bars". Consequently, being part of an incubator gave the start-up a strong competitive advantage. Silicon Valley incubators in particular tried to connect start-ups to networks of investors, for example by organizing a 'demo day', during which all start-ups presented to a large group of investors in an attempt to raise capital. Incubators also connected their start-ups to banks, corporates or government funds. Again, the incubator acts as a quality filter, as one member of a grant review panel illustrated: "You probably had to go through some sort of selection process to get admitted in an incubator. Even if it's as simple as talking about your technology a little bit. That's the kind of filter that even on a minimal level is important on a grant application”. For corporates, incubators were not only a filter, but, by partnering with them, also a way to create a more 'entrepreneurial' company image, to attract talented future employees, or to engage in demand driven open innovation strategies. One of the Israeli incubators asked its corporate partners to identify challenges in their company, after which the incubator selected start-ups that offered potential solutions to these challenges. For the incubator, these partnerships may be an additional source of revenue.

\subsubsection{Enable start-ups to be capital efficient}

Next to providing funds, incubators enabled start-ups to be 'capital efficient', by cutting the start-up's expenses. Besides facilitating access to economies of scale and providing subsidized office space, we also found incubators to negotiate deals with service providers (such as software companies or lawyers). Consequently, incubators can provide start-ups with 'perks' (e.g. free software or legal services) worth tens of thousands of dollars.

\subsubsection{Create a separate joint fund}

One of the Silicon Valley incubators had a separate early stage venture capital fund, in which it invested together with local investors and corporates. However, It should be noted that such a fund may also constrain the ability of start-ups to raise funding from external investors, as it may provide a negative signal when the incubator's fund decides not to invest in a particular start-up, as one entrepreneur illustrated: "That's very confusing, to 
have a VC arm judging startups.... I think it's a conflict of interest. It's confusing to the outside world. 'You're in the incubator, but they're not investing in you? What's going on?'. This signaling issue can be overcome by ensuring that, although the incubator may help in creating the fund and finding partners, the fund has no official affiliation with the incubator, and that it is not only bound to invest in start-ups from the incubator.

With the exception of the third practice, these practices create networks between startups and investors. The first two practices enable start-ups to make better use of the existing funds available in the entrepreneurial ecosystem. The incubator thereby does not address the institutions that cause the lack of early stage capital. By creating a separate joint fund, the incubator has the potential to extend the pool of investors. In addition, by co-investing and by acting as a filter to investors, the incubator mitigates some of the risks associated with investing in start-ups. The incubator thereby addresses the risk-averse cultural institution that partly causes the lack of early stage capital. Inspired by Silicon Valley success stories, we found Western European incubators to connect start-ups to investors by organizing demo days. However, we argue that the potential to do so is limited, due to the underdeveloped capital services and because Western European incubators often lack the track record and selectiveness to raise the interest of investors. Moreover, attracting venture funding may conflict with entrepreneurs' desire to stay in control of their start-up.

\subsection{Universities are not focused on entrepreneurship}

Incubators may use several practices to improve the interaction between start-ups and universities.

\subsubsection{Provide access to technical expertise and equipment}

. By providing introductions to university staff and technology transfer offices, the incubator enables start-ups to access scientific knowledge that may give them a competitive advantage. Start-ups can access such knowledge by involving university staff as personnel, as consultants or as advisory board members. Start-ups may also benefit from accessing university specialized equipment, such as a wind tunnel or gene sequencing equipment. However, negotiating terms of use with the university was perceived as an obstacle. Incubators may help by, in addition to contacts, providing standardized contracts. These contracts ensure that the start-up's IP is protected, and enable start-ups affiliated with the incubator to have more favorable terms.

\subsubsection{Mediate in internships}

Start-ups perceived the university as a valuable source of talented interns that can effectively transfer knowledge and technology from the university to the start-up. One university representative from the Boston area perceived internships as "one of the most effective ways" to foster relationships between universities and start-ups. However, there are several barriers to start-up internships. Start-ups were concerned about the time required to host interns, students found it difficult to connect to start-ups, as they did not post internships on their website, and universities were concerned about the uncertain nature of start-ups: "start-ups can blow up or implode. I think that we may be hesitant to devote too much time and energy to finding internships in start-ups because start-ups are very volatile". Incubators can mitigate these concerns. One of the Boston incubators 
organized 'intern fairs' to connect interns to start-ups. Further, incubators may help by providing standardized internship agreements, or by guaranteeing internships and placing interns at different start-ups when the original hosting start-up exits the market.

\subsubsection{Complement university curriculum}

One of the university-affiliated incubators in the Boston area organized courses, such as project-based marketing courses or business plan competitions, together with universities, and hosted the courses at the incubator facility. The incubator also provided course material through case studies or projects at start-ups. One interviewee said that the incubator thereby extends the university's theoretical curriculum with 'implementation education' that is more practical and hands-on. Another interviewee said that the incubator is 'co-curricular' as it complements the university's traditional courses: "If the next Facebook were to come out of this [incubator] no one would complain but that is not the main goal because they're students, they're here for school ... This execution part is still educational. And after they have left [the university], if they want to execute on something else, they'll be better prepared".

\subsubsection{Create a student board}

One of the incubators had created a 'student board' that organized guest lectures, coordinated workshops, and facilitated internships at start-ups. Both students and university staff found that the student board played an important role in fostering an entrepreneurial culture at the university. Having student members in the board creates close relationships between the incubator and the student community, and the board thereby creates a bridge between students and start-ups.

The above practices are focused on facilitating interaction between start-ups and university staff or students. By doing so, the incubator fosters a culture of ambitious entrepreneurship at universities, and provides start-ups with high quality scientific and entrepreneurial skills that are required for building a start-up with potential for high growth. However, the practices do not aim to change the regulatory incentives that make entrepreneurship an underexposed topic at universities. Further, although incubators may contribute to creating an entrepreneurial culture among students and university staff, the interviews suggest that the potential to do so is limited. One of the incubator managers said that the university culture takes a long time to change, and compared universities to an 'oil tanker' ship whose direction is difficult to change due to its size and momentum. Consequently, these practices primarily aim to facilitate entrepreneurship in a given institutional environment.

\section{Discussion and conclusion}

The five challenges faced by Western European start-ups all contribute to the main problem for start-ups to scale their activities and grow into high impact businesses. All of these challenges have institutional roots, which makes it difficult to overcome them entirely. Most of the identified practices that address these challenges are based on connecting the start-up to other actors. Based on these practices we conclude that the concepts of 'networked incubators' (Bøllingtoft and Ulhøi 2005; Hansen et al. 2000) and 'third 
generation incubators' (Aerts et al. 2007; Bruneel et al. 2012) are still applicable to the prominent entrepreneurial ecosystems we studied.

We contribute to the extant literature by providing deeper insights on the incubator's role in the entrepreneurial ecosystem. Incubators can directly provide some of the resources that entrepreneurial ecosystems require, such as financial capital, mentorship or a physical infrastructure. Moreover, their emphasis on connecting start-ups to each other and to other actors means that incubators can play an important role in strengthening the ecosystem's networks. Regarding the ecosystem's institutions, our findings suggest that incubators address challenges in the entrepreneurial ecosystem by mitigating the effects of unfavorable institutions. Incubators do so by creating a 'safe haven' that protects start-ups from these institutions or by bridging institutional differences between actors or countries. As such, incubators do not address the institutional causes of malfunctioning entrepreneurial ecosystems but provide symptomatic solutions instead. Consequently, whereas prior studies emphasized the potential of incubator's in contributing to entrepreneurial ecosystems (see e.g. Clarysse and Wright 2015; Fernández et al. 2012; Tsai et al. 2009), our study points at the limitations of incubators in strengthening the entrepreneurial ecosystem.

This finding also has important implications for policy makers and incubator managers. Policy makers should be aware that incubators are only a partial solution to institutional problems that run too deep for any single incubator to solve. If start-ups are indeed considered to be a vital component of future Western European economic growth, it is necessary to change the underlying regulations and cultural attitudes. Incubators can play a role in this process by acting as institutional entrepreneurs. Therefore, we call for a 'fourth generation' of 'systemic' incubators that aim to transform or create institutions to strengthen the entrepreneurial ecosystem (DiMaggio 1988). By doing so, these incubators would have the potential to improve the entrepreneurial ecosystem as a whole. Although questions are being raised on the effectiveness of many European incubators, there are also some incubators that have been around for many years and have created a track record of supporting successful start-up. As such, they have established themselves as legitimate actors in the entrepreneurial ecosystem. This, combined with the networks among incubated start-ups that enable incubators to take collective action, puts these incubators in a good position to engage in institutional entrepreneurship. They can do so for example by lobbying for start-up friendly regulations at a national or European level. Or they could try to influence the national culture by organizing events that reach a national audience in promoting successful role models. A first step towards this fourth generation incubators can be found in the European Accelerator Assembly (Accelerator Assembly 2015), which aims to strengthen Europe's entrepreneurial ecosystem by connecting the incubator community to European policy makers.

Strengthening entrepreneurial ecosystems by transforming institutions will likely take years. Until then, incubator managers and policy makers may use the incubation practices that we identified to address the challenges faced by start-ups. We also recommend policy makers to address the dependence of Western European incubators on public funds (Aerts et al. 2007; Barbero et al. 2014), as this contributes to the lack of market orientation of start-ups. It also encourages start-up quantity over quality. Such 'low selectivity' strategies (Clarysse et al. 2005; Degroof and Roberts 2004) do not seem appropriate in the Western European context, as our findings suggest that Europe does not suffer from a lack of start-ups in general, but of a lack of start-ups that experience growth. Accordingly, we recommend incubators to be more selective by focusing on supporting start-ups with potential for high growth, and to explore funding streams in addition to public funds. One suggestion would be for incubators to partner with corporates, as we have seen for example in the Israeli case. 
We end our paper with some limitations and avenues for further research. First, we are aware of cross country institutional differences within Western Europe that may affect the severity of the challenges we identified (Bosma and Schutjens 2011). However, as our findings are in line with European policies and studies, we are confident that the five challenges play a role in every Western European country, and that the variation lies mostly in the strength of certain challenges. Given that the aim of our research was to identify challenges without measuring their relative importance, further research is necessary to provide deeper insights into the importance of these challenges and the influence of country specific influences. The second limitation is related to our qualitative research design. We opted for a qualitative approach because, by relying on the knowledge and perceptions of interviewees to inform us, it enabled us to inductively identify incubation practices that have the potential to address the challenges faced by Western European startups. Given that we derived these practices from incubators in successful entrepreneurial ecosystems, we believe that these practices are an important first step towards more effective incubators. However, our qualitative approach did not allow us to verify the effectiveness of these practices. Consequently, we encourage future research to take the next step by quantitatively testing if incubators in general, and the incubation practices that we identified in particular, indeed address the challenges that we identified and thereby contribute to the success of European start-ups.

Open Access This article is distributed under the terms of the Creative Commons Attribution 4.0 International License (http://creativecommons.org/licenses/by/4.0/), which permits unrestricted use, distribution, and reproduction in any medium, provided you give appropriate credit to the original author(s) and the source, provide a link to the Creative Commons license, and indicate if changes were made.

\section{Appendix 1: List of questions for entrepreneurs}

\section{Introduction}

1. Could you briefly describe your personal background? (e.g. entrepreneurial experience, education).

2. What were your motivations to become an entrepreneur?

\section{Context}

3. What do you consider to be weak and strong points of the entrepreneurial ecosystem your start-up operates in? (e.g., capital market, entrepreneurial community, regulations, overall culture: risk taking, ambition, status of entrepreneurs, etc.)

4. Do you have any suggestions to increase the emergence and growth of start-ups in your industry?

\section{Incubator}

5. What were your reasons to join this incubator?

6. In terms of support provided by the incubator, what has been most valuable?

7. How would you describe your relationship with the incubator? (e.g. formal, informal, how often do you meet, who takes the initiative for support, etc.) 


\section{Appendix 2: List of questions for facilitators}

\section{Introduction}

1. Could you briefly describe your personal background? (e.g. entrepreneurial experience, education).

2. What are your responsibilities within this incubator?

\section{Context}

3. How would you describe the entrepreneurial ecosystem?

(a) What are strengths and weaknesses? (E.g. regulations, availability of capital, level of ambition, culture, etc.)

4. What would you change to strengthen the entrepreneurial ecosystem for start-ups

\section{Incubator}

5. Can you describe the background of the incubator?

(a) E.g. when was it founded, with what purpose, annual budget, size in terms of employees and start-ups.

6. What does your business model look like; how is the incubator financed?

7. What does your incubation process look like? (e.g., do you identify different phases? What kind of support do you provide?

8. What do you think is most important in the support offered by the incubator?

9. Do you see any patterns or common mistakes made by start-ups?

\section{Appendix 3: Supporting material}

\begin{tabular}{|c|c|c|c|c|c|}
\hline & $\begin{array}{l}\text { Lack of market } \\
\text { orientation }\end{array}$ & $\begin{array}{l}\text { Lack of } \\
\text { entrepreneurial } \\
\text { culture }\end{array}$ & $\begin{array}{l}\text { Small domestic } \\
\text { market }\end{array}$ & $\begin{array}{l}\text { Lack of early } \\
\text { stage capital }\end{array}$ & $\begin{array}{l}\text { Universities not } \\
\text { focused on } \\
\text { entrepreneurship }\end{array}$ \\
\hline Europe & $\begin{array}{l}\text { "If you look at } \\
\text { the main } \\
\text { critics that are } \\
\text { given outside } \\
\text { on the } \\
\text { ecosystem in } \\
\text { Europe }(. . .) \text {. } \\
\text { First is, the } \\
\text { companies are } \\
\text { not close } \\
\text { enough to the } \\
\text { market" }\end{array}$ & $\begin{array}{l}\text { "[There] is a lack } \\
\text { of sense of } \\
\text { urgency. It has } \\
\text { to go up, fast. } \\
\text { (...) You need } \\
\text { ambition" }\end{array}$ & $\begin{array}{l}\text { "European } \\
\text { people always } \\
\text { talk about } \\
\text { how } \\
\text { fragmented } \\
\text { the markets } \\
\text { here are and } \\
\text { small } \\
\text { compared to } \\
\text { the US" }\end{array}$ & $\begin{array}{l}\text { "There is } \\
\text { still not } \\
\text { enough } \\
\text { access to } \\
\text { finance. } \\
\text { That is the } \\
\text { same } \\
\text { problem in } \\
\text { the rest of } \\
\text { Europe" }\end{array}$ & \\
\hline
\end{tabular}




\begin{tabular}{|c|c|c|c|c|c|}
\hline & $\begin{array}{l}\text { Lack of market } \\
\text { orientation }\end{array}$ & $\begin{array}{l}\text { Lack of } \\
\text { entrepreneurial } \\
\text { culture }\end{array}$ & $\begin{array}{l}\text { Small domestic } \\
\text { market }\end{array}$ & $\begin{array}{l}\text { Lack of early } \\
\text { stage capital }\end{array}$ & $\begin{array}{l}\text { Universities not } \\
\text { focused on } \\
\text { entrepreneurship }\end{array}$ \\
\hline Netherlands & $\begin{array}{l}\text { "Being } \\
\text { vulnerable, } \\
\text { exploring the } \\
\text { market side, } \\
\text { they often do } \\
\text { not like this... } \\
\text { Selling your } \\
\text { product, } \\
\text { really making } \\
\text { clear 'this is } \\
\text { what I do', } \\
\text { that's a thing } \\
\text { that a lot of } \\
\text { entrepreneurs } \\
\text { struggle } \\
\text { with" }\end{array}$ & $\begin{array}{l}\text { "When you stick } \\
\text { your head up, } \\
\text { people don't } \\
\text { like it. This is } \\
\text { reflected into } \\
\text { all kinds of } \\
\text { dimensions: } \\
\text { stand up when } \\
\text { you have } \\
\text { something to } \\
\text { say, } \\
\text { presentation } \\
\text { skills, having a } \\
\text { big mouth, you } \\
\text { name it. That } \\
\text { slows down the } \\
\text { entrepreneurial } \\
\text { spirit" }\end{array}$ & $\begin{array}{l}\text { "You can't take } \\
\text { the European } \\
\text { market all at } \\
\text { once (...). It's } \\
\text { not possible to } \\
\text { put some } \\
\text { smart people } \\
\text { together, have } \\
\text { them think } \\
\text { about a } \\
\text { brilliant idea, } \\
\text { and then just } \\
\text { take the entire } \\
\text { market." }\end{array}$ & $\begin{array}{l}\text { "A big } \\
\text { difference } \\
\text { in the US } \\
\text { is (...) the } \\
\text { exit } \\
\text { climate is } \\
\text { much } \\
\text { better } \\
\text { there. That } \\
\text { makes it } \\
\text { more } \\
\text { attractive } \\
\text { for an } \\
\text { investor to } \\
\text { be in the } \\
\text { valley, } \\
\text { because } \\
\text { you know } \\
\text { that when } \\
\text { a business } \\
\text { really } \\
\text { takes off } \\
\text { that there } \\
\text { are } \\
\text { multiple } \\
\text { actors in } \\
\text { the stage } \\
\text { after that } \\
\text { who are } \\
\text { interested" }\end{array}$ & $\begin{array}{l}\text { "I hear from many } \\
\text { entrepreneurs that } \\
\text { the process of } \\
\text { negotiating IP } \\
\text { with the } \\
\text { universities is a } \\
\text { tough process" }\end{array}$ \\
\hline France & $\begin{array}{l}\text { "Often } \\
\text { companies } \\
\text { which are } \\
\text { began by } \\
\text { scientists, } \\
\text { communicate } \\
\text { on how } \\
\text { brilliant their } \\
\text { technology is. } \\
\text { They don't } \\
\text { think in terms } \\
\text { of customer" }\end{array}$ & $\begin{array}{l}\text { "In France, }(\ldots) \\
\text { you tend to feel } \\
\text { superior if you } \\
\text { work for a very } \\
\text { large company. } \\
\text { It is very } \\
\text { difficult for a } \\
\text { young startup } \\
\text { to be accepted } \\
\text { and taken } \\
\text { serious" }\end{array}$ & & & $\begin{array}{l}\text { "I would be } \\
\text { extremely } \\
\text { grateful to have } \\
\text { the opportunity to } \\
\text { have access to } \\
\text { academic } \\
\text { institutions" }\end{array}$ \\
\hline
\end{tabular}




\begin{tabular}{|c|c|c|c|c|c|}
\hline & $\begin{array}{l}\text { Lack of market } \\
\text { orientation }\end{array}$ & $\begin{array}{l}\text { Lack of } \\
\text { entrepreneurial } \\
\text { culture }\end{array}$ & $\begin{array}{l}\text { Small domestic } \\
\text { market }\end{array}$ & $\begin{array}{l}\text { Lack of early } \\
\text { stage capital }\end{array}$ & $\begin{array}{l}\text { Universities not } \\
\text { focused on } \\
\text { entrepreneurship }\end{array}$ \\
\hline Switzerland & $\begin{array}{l}\text { "Another } \\
\text { question is } \\
\text { whether the } \\
\text { people that } \\
\text { have done the } \\
\text { research here } \\
\text { are the right } \\
\text { people for } \\
\text { starting a } \\
\text { company } \\
\text { That's more } \\
\text { difficult (...) } \\
\text { You need } \\
\text { knowledge } \\
\text { from people } \\
\text { that come } \\
\text { from the field } \\
\text { where the } \\
\text { startup is } \\
\text { active. (...) } \\
\text { For the } \\
\text { business plan. } \\
\text { To tell what } \\
\text { works and } \\
\text { what doesn't" }\end{array}$ & $\begin{array}{l}\text { "All of your } \\
\text { friends are } \\
\text { going into } \\
\text { consulting. } \\
\text { Everybody } \\
\text { asks: why don't } \\
\text { you go to BCG } \\
\text { or McKinsey?" }\end{array}$ & $\begin{array}{l}\text { "We are a little } \\
\text { in a } \\
\text { disadvantage, } \\
\text { regarding } \\
\text { financial } \\
\text { possibilities } \\
\text { here (...). We } \\
\text { are a small } \\
\text { country, the } \\
\text { funds that are } \\
\text { available or } \\
\text { on a smaller } \\
\text { scale. We talk } \\
\text { about a few } \\
\text { hundred } \\
\text { thousands up } \\
\text { to a few } \\
\text { millions. } \\
\text { Large } \\
\text { investments } \\
\text { are not } \\
\text { frequent" }\end{array}$ & $\begin{array}{l}\text { "It is much } \\
\text { better } \\
\text { organized } \\
\text { today. The } \\
\text { funds are } \\
\text { bigger than } \\
\text { before. But } \\
\text { it is far less } \\
\text { than what } \\
\text { we see at } \\
\text { the US" }\end{array}$ & $\begin{array}{l}\text { "I had to be really } \\
\text { stubborn (...) } \\
\text { Having seen at } \\
\text { MIT how they } \\
\text { handle } \\
\text { entrepreneurship, } \\
\text { it is really hard } \\
\text { (...). Especially } \\
\text { when you want to } \\
\text { find an } \\
\text { application for } \\
\text { the technology. } \\
\text { Phd's do not look } \\
\text { like at it that way. } \\
\text { The willingness } \\
\text { to step out of the } \\
\text { comfort zone is } \\
\text { not there" }\end{array}$ \\
\hline Germany & $\begin{array}{l}\text { "Lots of people } \\
\text { are working } \\
\text { on their } \\
\text { product and } \\
\text { do the } \\
\text { prototyping } \\
\text { and then they } \\
\text { realize there } \\
\text { might not be a } \\
\text { market for it" }\end{array}$ & $\begin{array}{l}\text { "Also the anti- } \\
\text { failure culture, } \\
\text { as opposite to } \\
\text { the US. Here its } \\
\text { more doubtful } \\
\text { and fearful" }\end{array}$ & $\begin{array}{l}\text { "if you go to for } \\
\text { instance the } \\
\text { US there is a } \\
\text { big home } \\
\text { demand (...) } \\
\text { The market } \\
\text { here is smaller } \\
\text { (...). We then } \\
\text { could use } \\
\text { whatever we } \\
\text { build up here } \\
\text { to kickstart } \\
\text { somewhere } \\
\text { else" }\end{array}$ & $\begin{array}{l}\text { "The access } \\
\text { to capital } \\
\text { is also } \\
\text { weaker } \\
\text { than in the } \\
\text { US (...) } \\
\text { One of the } \\
\text { big } \\
\text { challenges } \\
\text { is growth } \\
\text { capital, } \\
\text { series A \& } \\
\text { B. Not the } \\
\text { very seed- } \\
\text { funding, } \\
\text { but little } \\
\text { later like } \\
\text { VCs and } \\
\text { angels" }\end{array}$ & \\
\hline
\end{tabular}

\section{References}

Accelerator Assembly. (2015). Accelerator Assembly. http://www.acceleratorassembly.eu/. Accessed 11 Sept 2015.

Ács, Z. J., Autio, E., \& Szerb, L. (2014). National systems of entrepreneurship: Measurement issues and policy implications. Research Policy, 43(3), 476-494. doi:10.1016/j.respol.2013.08.016. 
Aernoudt, R. (2004). Incubators: Tool for entrepreneurship? Small Business Economics, 23, 127-135. doi:10.1023/B:SBEJ.0000027665.54173.23.

Aerts, K., Matthyssens, P., \& Vandenbempt, K. (2007). Critical role and screening practices of European business incubators. Technovation, 27(5), 254-267. doi:10.1016/j.technovation.2006.12.002.

Ahmad, A. J., \& Ingle, S. (2013). Business incubators and HTSF development: Setting an agenda for further research. In R. Oakey, A. Groen, C. Cook, \& P. Van Der Sijde (Eds.), New technology-based firms in the new millenium (Vol. X, pp. 119-140). Bingley: Emerald Group Publishing Limited.

Amezcua, A. S., Grimes, M. G., Bradley, S. W., \& Wiklund, J. (2013). Organizational sponsorship and founding environments: A contingency view on the survival of BUSINESS incubated firms, 1994-2007. Academy of Management Journal, 56(6), 1628-1654. doi:10.5465/amj.2011.0652.

Audretsch, D., Thurik, R., Verheul, I., \& Wennekers, A. R. (2002). Entrepreneurship: Determinants and policy in a European-US comparison. Boston: Kluwer Academic Publishers.

Barbero, J. L., Casillas, J. C., Ramos, A., \& Guitar, S. (2012). Revisiting incubation performance. Technological Forecasting and Social Change, 79(5), 888-902. doi:10.1016/j.techfore.2011.12.003.

Barbero, J. L., Casillas, J. C., Wright, M., \& Ramos Garcia, A. (2014). Do different types of incubators produce different types of innovations? The Journal of Technology Transfer, 39(2), 151-168. doi:10. 1007/s10961-013-9308-9.

Barrow, C. (2001). Incubators: A realist's guide to the world's new business accelerators. West Sussex: Wiley.

Bartelsman, E. (2005). Comparative analysis of firm demographics and survival: Evidence from micro-level sources in OECD countries. Industrial and Corporate Change, 14(3), 365-391. doi:10.1093/icc/ dth057.

Bergek, A., \& Norrman, C. (2008). Incubator best practice: A framework. Technovation, 28, 20-28. doi:10. 1016/j.technovation.2007.07.008.

Bergek, A., \& Norrman, C. (2015). Integrating the supply and demand sides of public support to NTBFs: A typology with implications for policy makers. Science and Public Policy, 42(4), 514-529. doi:10.1093/ scipol/scu072.

Blank, S. (2013). Why the lean start-up changes everything. Harvard Business Review, 91(5), 63-72.

Blumer, H. (1954). What is wrong with social theory? American Sociological Review, 19(1), 3-10.

Bøllingtoft, A., \& Ulhøi, J. P. (2005). The networked business incubator-Leveraging entrepreneurial agency? Journal of Business Venturing, 20(2), 265-290. doi:10.1016/j.jbusvent.2003.12.005.

Bosma, N., \& Schutjens, V. (2011). Understanding regional variation in entrepreneurial activity and entrepreneurial attitude in Europe. The Annals of Regional Science, 47(3), 711-742. doi:10.1007/ s00168-010-0375-7.

Bottazzi, L., \& Da Rin, M. (2002). Venture capital in Europe and the financing of innovative companies. Economic Policy, 34, 229-269. doi:10.1111/1468-0327.00088.

Bravo-biosca, A. (2011). A look at business growth and contraction in Europe (No. 11/02).

Brown, R., \& Mason, C. (2014). Inside the high-tech black box: A critique of technology entrepreneurship policy. Technovation, 34(12), 773-784. doi:10.1016/j.technovation.2014.07.013.

Brown, R., \& Mawson, S. (2015). Targeted support for high growth firms: Theoretical constraints, unintended consequences and future policy challenges. Environment and Planning C: Government and Policy, Forthcoming. doi:10.1177/0263774X15614680.

Bruneel, J., Ratinho, T., Clarysse, B., \& Groen, A. (2012). The evolution of business incubators: Comparing demand and supply of business incubation services across different incubator generations. Technovation, 32, 110-121. doi:10.1016/j.technovation.2011.11.003.

Bryman, A. (2008). Social research methods (3rd ed.). Oxford: Oxford University Press.

Carlsson, B., \& Stankiewicz, R. (1991). On the nature, function and composition of technological systems. Journal of Evolutionary Economics, 1, 93-118.

Casper, S., \& Soskice, D. (2004). Patterns of innovation and variety of capitalism: Explaining the development of high-technology entrepreneurialism in Europe. In F. Malerba (Ed.), Sectoral systems of innovation: Concept, issues and analysis of six major sectors in Europe. Cambridge: Cambridge University Press.

Chandra, A., Alejandra, M., \& Silva, M. (2012). Business incubation in Chile: Development, financing and financial services. Journal of Technology Management \& Innovation, 7(2), 1-13.

Clarysse, B., Wright, M., \& Hove, J. Van. (2015). A look inside accelerators: building businesses. London. http://www.nesta.org.uk/publications/look-inside-accelerators.

Clarysse, B., Wright, M., Lockett, A., Van de Velde, E., \& Vohora, A. (2005). Spinning out new ventures: A typology of incubation strategies from European research institutions. Journal of Business Venturing, 20(2), 183-216. doi:10.1016/j.jbusvent.2003.12.004. 
Cohen, B. (2006). Sustainable valley entrepreneurial ecosystems. Business Strategy and the Environment, 15(1), 1-14. doi:10.1002/bse.428.

Cooper, C. E., Hamel, S. A., \& Connaughton, S. L. (2010). Motivations and obstacles to networking in a university business incubator. The Journal of Technology Transfer, 37(4), 433-453. doi:10.1007/ s10961-010-9189-0.

Corbin, J., \& Strauss, A. (1990). Grounded theory research: Procedures, canons, and evaluative criteria. Qualitative Sociology, 13(1), 4-21.

Degroof, J.-J., \& Roberts, E. B. (2004). Overcoming weak entrepreneurial infrastructures for academic spinoff ventures. The Journal of Technology Transfer, 29, 327-352. doi:10.1023/B:JOTT.0000034126. 23592.23.

DiMaggio, P. J. (1988). Interest and agency in institutional theory. In L. Zucker (Ed.), Institutional patterns and organizations (pp. 3-22). Cambridge, MA: Cambridge.

Etzkowitz, H. (2004). The evolution of the entrepreneurial university. International Journal of Technology and Globalisation, 1(1), 64-77.

European Commission. (2013). Entrepreneurship 2020 action plan-reigniting the entrepreneurial spirit in Europe, COM (2012) 795 final, European Commission, 9 January 2013. Brussels.

European Commission. (2014). Startup Europe partnership. http://ec.europa.eu/digital-agenda/en/startupeurope-partnership. Accessed 3 Jan 2015.

Feld, B. (2012). Startup communities: Building an entrepreneurial ecosystem in your city. Hoboken, NJ: Wiley.

Fernández, M. T. F., Martínez, A. F. A., \& Herrero, D. B. (2012). Promotion of social entrepreneurship through public services in the madrid region: Succesful aspects. Amfiteatru Economic, 14(6), 774-785.

Fiedler, M.-O., \& Hellmann, T. (2001). Against all odds: The late but rapid development of the German venture capital industry. The Journal of Private Equity, 4(4), 31-45.

Florida, R., Mellander, C., \& Stolarick, K. (2008). Inside the black box of regional development-human capital, the creative class and tolerance. Journal of Economic Geography, 8(5), 615-649.

Gioia, D. A., Corley, K. G., \& Hamilton, A. L. (2012). Seeking qualitative rigor in inductive research: Notes on the Gioia methodology. Organizational Research Methods, 16(1), 15-31. doi:10.1177/ 1094428112452151.

Goldfarb, B., \& Henrekson, M. (2003). Bottom-up versus top-down policies towards the commercialization of university intellectual property. Research Policy, 32(4), 639-658. doi:10.1016/S00487333(02)00034-3.

Grant, R. M. (1996). Toward a knowledge-based theory of the firm. Strategic Management Journal, 17, 109-122.

Hackett, S. M., \& Dilts, D. M. (2004a). A systematic review of business incubation research. The Journal of Technology Transfer, 29(1), 55-82. doi:10.1023/B:JOTT.0000011181.11952.0f.

Hackett, S. M., \& Dilts, D. M. (2004b). A real options-Driven theory of business incubation. The Journal of Technology Transfer. doi:10.1023/B:JOTT.0000011180.19370.36.

Hall, P., \& Soskice, D. (2001). Varieties of capitalism: The institutional foundations of comparative advantage. Oxford: Oxford University Press.

Hansen, M. T., Chesbrough, H. W., Nohria, N., \& Sull, D. N. (2000). Networked incubators. Hothouses of the new economy. Harvard Business Review, 78(5), 74-84.

Hekkert, M. P., Suurs, R. A. A., Negro, S. O., Kuhlmann, S., \& Smits, R. E. H. M. (2007). Functions of innovation systems: A new approach for analysing technological change. Technological Forecasting and Social Change, 74(4), 413-432. doi:10.1016/j.techfore.2006.03.002.

Herrmann, B. L., Marmer, M., Dogrultan, E., \& Holtschke, D. (2012). Startup Ecosystem Report 2012: Part One. http://blog.startupcompass.co/pages/entrepreneurship-ecosystem-report.

Hughes, M., Ireland, R. D., \& Morgan, R. E. (2007). Stimulating dynamic value: Social capital and business incubation as a pathway to competitive success. Long Range Planning, 40(2), 154-177. doi:10.1016/j. lrp.2007.03.008.

Kelley, D. J., Singer, S., \& Herrington, M. D. (2012). Global report: The global entrepreneurship monitor. Babson Park: Babson College.

Lalkaka, R. (2002). Technology business incubators to help build an innovation-based economy. Journal of Change Management, 3(2), 167-176. doi:10.1080/714042533.

Lee, S. S., \& Osteryoung, J. S. (2004). A comparison of critical success factors for effective operations of university business incubators in the United States and Korea. Journal of Small Business Management, 42(4), 418-426. doi:10.1111/j.1540-627X.2004.00120.x.

Lendner, C., \& Dowling, M. (2007). The organisational structure of university business incubators and their impact on the success of start-ups: An international study. International Journal of Entrepreneurship \& Innovation Management, 7(6), 541-555. 
Lewis, D. A. (2001). Does technology incubation work? A critical review, Reviews of economic development literature and practice, US Economic Development Administration, Department of Commerce. Washington, DC.

Mcadam, M., \& Marlow, S. (2007). Building futures or stealing secrets?: Entrepreneurial cooperation and conflict within business incubators. International Small Business Journal, 25(4), 361-382. doi:10. $1177 / 0266242607078563$.

McEvily, S. K., \& Chakravarthy, B. (2002). The persistence of knowledge-based advantage: An empirical test for product performance and technological knowledge. Strategic Management Journal, 23(4), 285-305. doi:10.1002/Smj.223.

Mian, S. (1997). Assessing and managing the university technology business incubator: An integrative framework. Journal of Business Venturing, 12(4), 251-285.

Mian, S. (2014). Business incubation and incubator mechanisms. In A. Fayolle (Ed.), Handbook of research on entreprepenurship: What we know and what we need to know (pp. 335-366). Cheltenham: Edward Elgar Publishing.

Michael, S. C., \& Pearce, J. A. (2009). The need for innovation as a rationale for government involvement in entrepreneurship. Entrepreneurship \& Regional Development, 21(3), 285-302. doi:10.1080/ 08985620802279999.

Neck, H. M., Meyer, G. D., Cohen, B., \& Corbett, A. C. (2004). An entrepreneurial system view of new venture creation. Journal of Small Business Management, 42(2), 190-208. doi:10.1111/j.1540-627X. 2004.00105.x.

NESTA. (2011). The startup factories: The rise of accelerator programmes to support new technology ventures. London. http://210.219.43.34/upload/policy/1310018323687.PDF. Accessed 17 September 2013.

North, D. C. (1990). Institutions, institutional change and economic performance. New York, NY: Cambridge University Press.

Oakey, R. (2012). High-technology entrepreneurship. London: Routledge.

Pacheco, D. F., York, J. G., Dean, T. J., \& Sarasvathy, S. D. (2010). The coevolution of institutional entrepreneurship: A tale of two theories. Journal of Management, 36(4), 974-1010. doi:10.1177/ 0149206309360280.

Patton, D., \& Marlow, S. (2011). University technology business incubators: Helping new entrepreneurial firms to learn to grow. Environment and Planning C: Government and Policy, 29(5), 911-926. doi:10. 1068/c10198b.

Phan, P. H., Siegel, D. S., \& Wright, M. (2005). Science parks and incubators: Observations, synthesis and future research. Journal of Business Venturing, 20(2), 165-182. doi:10.1016/j.jbusvent.2003.12.001.

Philippon, T., \& Véron, N. (2008). Financing Europe's fast movers. In Bruegel Policy Brief 1/2008.

PWC and Google. (2013). The startup economy-How to support tech startups and accelerate Australian innovation. http://www.digitalpulse.pwc.com.au. Accessed 10 Jan 2014.

Rice, M. P. (2002). Co-production of business assistance in business incubators: An exploratory study. Journal of Business Venturing, 17(2), 163-187. doi:10.1016/S0883-9026(00)00055-0.

Ries, E. (2011). The lean startup. New York: Crown Publishing Group.

Rothaermel, F. T., Agung, S. D., \& Jiang, L. (2007). University entrepreneurship: A taxonomy of the literature. Industrial and Corporate Change, 16(4), 691-791. doi:10.1093/icc/dtm023.

Salido, E., Sabás, M., \& Freixas, P. (2013). The accelerator and incubator ecosystem in Europe. http://www. lisboncouncil.net/component/downloads/?id=897. Accessed 5 Jan 2015.

Scarpetta, S., Hemmings, P., Tressel, T., \& Woo, J. (2002). The role of policy and institutions for productivity and firm dynamics: Evidence from micro and industry data (No. 329). Paris.

Schneider, C., \& Veugelers, R. (2010). On young highly innovative companies: Why they matter and how (not) to policy support them. Industrial and Corporate Change, 19(4), 969-1007.

Schwartz, M. (2009). Beyond incubation: An analysis of firm survival and exit dynamics in the postgraduation period. The Journal of Technology Transfer, 34(4), 403-421. doi:10.1007/s10961-0089095-x.

Schwartz, M. (2013). A control group study of incubators' impact to promote firm survival. The Journal of Technology Transfer, 38(3), 302-331. doi:10.1007/s10961-012-9254-y.

Scott, W. R. (1995). Institutions and organizations. Thousand Oaks, CA: Sage Publications Inc.

Senor, D., \& Singer, S. (2009). Start-up nation: The story of Israel's economic miracle. New York: Twelve Hachette Book Group.

Spigel, B. (2015). The relational organization of entrepreneurial ecosystems. Entrepreneurship Theory and Practice, Forthcoming. doi:10.1111/etap.12167.

Stam, E. (2015). Entrepreneurial ecosystems and regional policy: A sympathetic critique. European Planning Studies, 23(9), 1759-1769. doi:10.1080/09654313.2015.1061484. 
Startup Manifesto. (2013). Startup Europe-A manifesto for entrepreneurship and innovation to power growth in the EU. http://startupmanifesto.eu/. Accessed 3 Jan 2015.

Tamásy, C. (2007). Rethinking technology-oriented business incubators: Developing a robust policy instrument for entrepreneurship, innovation, and regional development. Growth and Change, 38(3), 460-473. doi:10.1111/j.1468-2257.2007.00379.x.

Tavoletti, E. (2013). Business incubators: Effective infrastructures or waste of public money? Looking for a theoretical framework, guidelines and criteria. Journal of the Knowledge Economy, 4(4), 423-443. doi:10.1007/s13132-012-0090-y.

Terjesen, S., Hessels, J., \& Li, D. (2013). Comparative international entrepreneurship: A review and research agenda. Journal of Management. doi:10.1177/0149206313486259.

The Economist. (2012). Les misérables. http://www.economist.com/node/21559618. Accessed 5 Jan 2015.

Tijssen, R. J. W., \& van Wijk, E. (1999). In search of the European paradox: An international comparison of Europe's scientific performance and knowledge flows in information and communication technologies research. Research Policy, 28(5), 519-543. doi:10.1016/S0048-7333(99)00011-6.

Totterman, H., \& Sten, J. (2005). Start-ups: Business incubation and social capital. International Small Business Journal, 23(5), 487-511. doi:10.1177/0266242605055909.

Trimi, S., \& Berbegal-Mirabent, J. (2012). Business model innovation in entrepreneurship. International Entrepreneurship and Management Journal, 8, 449-465. doi:10.1007/s11365-012-0234-3.

Tsai, F.-S., Hsieh, L. H. Y., Fang, S.-C., \& Lin, J. L. (2009). The co-evolution of business incubation and national innovation systems in Taiwan. Technological Forecasting and Social Change, 76(5), 629-643. doi:10.1016/j.techfore.2008.08.009.

United Nations Statistics Division. (2015). Composition of macro geographical (continental) regions, geographical sub-regions, and selected economic and other groupings. http://unstats.un.org/unsd/ methods/m49/m49regin.htm. Accessed 8 Sept 2015.

Van Rijnsoever, F. J., van den Berg, J., Koch, J., \& Hekkert, M. P. (2015). Smart innovation policy: How network position and project composition affect the diversity of an emerging technology. Research Policy, 44(5), 1094-1107. doi:10.1016/j.respol.2014.12.004.

van Rijnsoever, F. J., Welle, L., \& Bakker, S. (2014). Credibility and legitimacy in policy-driven innovation networks: Resource dependencies and expectations in Dutch electric vehicle subsidies. The Journal of Technology Transfer, 39(4), 635-661. doi:10.1007/s10961-013-9326-7.

van Weele, M., van Rijnsoever, F. J., \& Nauta, F. (2016). You can't always get what you want: How entrepreneur's perceived resource needs affect the incubator's assertiveness. Technovation. doi:10. 1016/j.technovation.2016.08.004. (in press).

van Weele, M., Van Rijnsoever, F. J., \& Steinz, H. (2014). Start-ups down under: How start-up communities facilitate Australian entrepreneurship. In Druid Conference 2014. Copenhagen.

WEF. (2013). Entrepreneurial ecosystems around the globe and company growth dynamics. Davos. http:// www3.weforum.org/docs/WEF_EntrepreneurialEcosystems_Report_2013.pdf.

Wilson, K. (2008). Entrepreneurship education in Europe. In J. Potter (Ed.), Entrepreneurship and higher education (pp. 119-138). Paris: OECD. 